\title{
Pengembangan Multimedia Sistem Tata Surya Pada Muatan Ipa Kelas VI
}

\section{Wahyu Permadi Putra ${ }^{1 *}$, Drs. I Gusti Agung Oka Negara ${ }^{2}$}

12 Prodi Pendidikan Guru Sekolah Dasar, Universitas Pendidikan Ganesha, Singaraja, Indonesia *e-mail: wahyupermadiputra03@undiksha.ac.id

\begin{abstract}
Abstrak
Kurangnya media pembelajaran yang membantu siswa dalam belajar membuat siswa sulit memahami materi pelajaran. Penelitian ini bertujuan untuk mendeskripsikan proses rancang bangun dari produk Multimedia sistem tata surya dan mengetahui hasil validasi produk Multimedia sistem tata surya menurut hasil review para ahli dan uji coba perorangan. Penelitian pengembangan ini menggunakan model ADDIE (Analyzed, Design, Development, Implementation, Evaluation). Pengumpulan data menggunakan metode kuesioner. Analisis data menggunakan metode analisis deskriptif kuantitatif. Hasil analisis data yang diperoleh yaitu ahli isi muatan pelajaran IPA memperoleh skor 87,50 (sangat baik), ahli desain instruksional memperoleh skor 93,75 (sangat baik), ahli media pembelajaran memperoleh skor 91,66 (sangat baik) dan hasil uji coba perorangan memperoleh skor 92,30 (sangat baik). Berdasarkan hasil analisis data uji produk oleh para ahli dan hasil uji coba perorangan, dapat disimpulkan bahwa produk Multimedia sistem tata surya ini layak digunakan pada materi tata surya kelas VI. Implikasi penelitian ini adalah memberikan sebuah media pembelajaran inovatif yang dapat membantu siswa dalam belajar sehingga berdampak pada hasil belajar siswa yang meningkat.
\end{abstract}

Kata kunci: multimedia sistem tata surya, ADDIE, IPA

\begin{abstract}
Lack of learning media that helps students in learning makes it difficult for students to understand the subject matter. This study aims to describe the design process of the solar system multimedia product and to find out the validation results of the solar system multimedia product according to the results of expert reviews and individual trials. This development research uses the ADDIE (Analyzed, Design, Development, Implementation, Evaluation) model. Data collection using a questionnaire method. Data analysis using quantitative descriptive analysis method. The results of the data analysis were that the science subject content expert got a score of 87.50 (very good), the instructional design expert got a score of 93.75 (very good), the instructional media expert got a score of 91.66 (very good) and the results of the trial individuals obtained a score of 92.30 (very good). Based on the results of product test data analysis by experts and the results of individual trials, it can be concluded that this solar system multimedia product is suitable for use in class VI solar system material. The implication of this research is to provide an innovative learning media that can assist students in learning so that it has an impact on increased student learning outcomes.
\end{abstract}

Keywords: solar system multimedia, ADDIE, IPA

\section{Pendahuluan}

Semakin berkembangnya teknologi dan informasi memberikan dampak yang sangat besar di dalam bidang pendidikan (Warsihna, 2016; Wulandari, Sudatha, \& Simamora, 2020). Teknologi di era modern ini dapat digunakan sebagai penunjang dalam pembelajaran.

\footnotetext{
${ }^{*}$ Corresponding author.

Received 30 Januari 2021; Accepted 1 Maret 2021; Available online 8 April 2021 (c) 2021 MI All Rights Reserved
} 
Pengaruh tersebut terlihat jelas dalam pembaharuan sistem pendidikan dan pengembangan media pembelajaran. Diharapkan guru mampu memberikan inovasi-inovasi dalam mengembangkan media pembelajaran agar terciptanya proses pembelajaran menjadi lebih kreatif dan menarik. Proses pembelajaran dapat dilaksanakan dimanapun dan kapanpun, tidak hanya di sekolah saja tetapi di luar sekolah bahkan dirumah masih bisa melaksanakan proses pembelajaran (Irawan, 2018; Khamparia \& Pandey, 2017). Teknologi mempunyai perana penting dalam proses pembelajaran, guru dapat memanfaatkan teknologi untuk melaksanakan proses pembelajaran secara daring atau pembelajaran yang dilakukan tanpa melakukan tatap muka.

Saat ini dunia mengalami musibah dengan mewabahnya suatu virus yang bernama Corona atau yang sering disebut dengan Covid-19 (Corona 3 Virus Deseases-19) (Handayani, Hadi, Isbaniah, Burhan, \& Agustin, 2020; Susilo et al., 2020). Virus ini pertama kali mewabah di Kota Wuhan, Tiongkok dan menyebar dengan sangat cepat ke seluruh dunia, salah satu megara yang terkena dampak dari wabah ini adalah Indonesia. Wabah ini mempengaruhi banyak sekali sektor, mulai dari bidang ekonomi, sosial, hingga bidang pendidikan. Karena imbas dari munculnya virus ini di bidang pendidikan membuat Menteri Pendidikan dan Kebudayaan (Mendikbud) mengeluarkan surat edaran Nomor 4 Tahun 2020 tentang Pelaksanaan Kebijakan Pendidikan Dalam Masa Darurat Penyebaran Corona Virus Deseases-19. Agar dapat memutus rantai penyebaran virus ini pemerintah menganjurkan untuk menutup kegiatan pembelajaran di sekolah dan menerapkan pembelajaran daring (online). Akibat virus ini banyak guru yang masih kebingunan untuk melakukan proses pembelajaran secara online. Hal ini juga terjadi disalah satu sekolah dasar. Berdasarkan hasil observasi dan wawancara didapatkan bahwa dalam pelaksanaan pembelajaran daring masih banyak guru kebingungan dalam penerapan metode, model, media dan hal-hal lainnya yang berhubungan dengan proses pembelajaran daring. Guru hanya memberikan penugasan-penugasan kepada siswa, tanpa menggunakan alat peraga atau media pembelajaran, sehingga pelaksanaan pembelajaran menjadi kurang optimal. Dalam pelaksanaan pembelajaran daring, sangat sulit menerapkan media pembelajaran yang berbentuk tiga dimensi sehingga untuk membantu agar siswa lebih mudah memahami makna materi yang disajikan dalam pembelajaran dibutuhkan media yang sesuai dengan kebutuhan siswa dan mampu diterapkan ke dalam pembelajaran daring.

Berdasarkan permasalahan tersebut, maka salah satu solusi yang dapat dilakukan adalah dengan mengembangkan media pembelajaran yang dapat membantu siswa belajar secara daring. Pemakaian media pembelajaran sangat penting dalam mempermudah dan memperjelas dalam menyampaikan materi pembelajaran (Rosidah, 2016; Yusnia, 2019). Penyaluran pesan atau informasi dapat dilakukan melalui media pembelajaran sehingga hambatan dari sumber belajar dapat diminimalisir (Puspitorini, Subali, \& Jumadi, 2014; Qumillaila, Susanti, \& Zulfiani, 2017). Penerapan media pembelajaran di SD sangat penting karena pada tingkat sekolah dasar memiliki kemampuan yang terbatas dalam memahami materi yang bersifat abstrak. Salah satu materi pembelajaran yang dimaksudkan adalah tata surya, dimana materi ini membutuhkan sebuah media pembelajaran yang digunakan untuk menjelaskan atau membelajarkan siswa sehingga siswa mampu mengkongkritkan materi tersebut. Proses pelaksanaan pembelajaran pada materi tata surya pada umumnya, guru masih menggunakan gambar diam yang telah tersedia dalam buku teks sehingga membuat siswa cenderung pasif dan kurang tertarik karena media gambar tidak mampu memberikan respon timbal balik, kurang terlihat nyata dan kurang menarik bagi siswa. Sehingga, diperlukan media yang dapat mempermudah siswa dalam memahami materi tata surya, melibatkan siswa secara langsung, dan menarik yaitu melalui media pembelajaran berupa multimedia.

Media adalah sesuatu yang dapat digunakan untuk menyalurkan pesan sehingga dapat merangsang perhatian, minat, pikiran, dan perasaan peserta didik dalam kegiatan pembelajaran untuk mencapai tujuan (Asnur \& Ambiyar, 2018; Tegeh, Simamora, \& Dwipayana, 2019). Media pembelajaran selain berisikan suatu materi atau bahan ajar, dapat menarik atensi peserta didik, dan jugaa mengkonkretkan sesuatu yang abstrak. Mengingat 
peserta didik di sekolah dasar pada dalam tahapan Operasional konkret yaitu otaknya sudah mampu beroperasi dengan baik khususnya megenai segala sesuatu yang konkret, sehingga untuk membuat anak dapat berfikir abstrak masih membutuhkan media untuk sumber pembelajaran. Perkembangan teknologi yang semakin modern dapat membantu seseorang dalam menciptakan inovasi-inovasi baru dan meningkatkan kreatifitas sehingga dapat menciptakan media pembelajaran yang menarik dalam bentuk audio, visual, dan gerak (Novita, Sukmanasa, \& Pratama, 2019; Widjiningsih, Sugiyono, \& Gafur, 2014). Pentingnya penerapan media yang bisa digunakan dalam proses pembelajaran daring ini untuk membantu siswa memahami isi materi pembelajaran sehingga proses pembelajaran menjadi bermakna bagi siswa serta mengatasi masalah rendahnya minat siswa dalam proses pembelajaran adalah media yang dapat diakses siswa melalui smartphone mereka. Smartphone dilengkapi dengan internet dan aplikasinya dapat memudahkan seseorang untuk mengembangkan media pembelajaran yang menarik dalam bentuk audio, visual, dan gerak. Salah satu media pembelajaran yang dapat dikembangkan yaitu Multimedia sistem tata surya.

Multimedia adalah penggunaan komputer untuk menyajikan dan menggabungkan teks, suara, gambar, animasi dan video dengan alat bantu dan koneksi (link) sehingga pengguna dapat bernavigasi, berinteraksi, berkarya dan berkomunikasi (Antari, Sujana, \& Wiarta, 2013; Irwanto, Taufik, Hernawan, \& Rizal, 2019). Multimedia merupakan media yang menggabungkan aspek visual dan audio sehingga dapat dipahami oleh siswa yang memiliki gaya belajar berbeda dengan mudah (Nazalin \& Muhtadi, 2016; Pangaribuan \& Saragih, 2014). Multimedia ini memiliki elemen yang terdiri atas gambar, tes, animasi, suara, dan video. Multimedia mentransmisikan informasi menggunakan unsur teks, audio, grafis, dan interaktifitas. Interaktifitas diartikan sebagai komponen navigasi. Kelebihan dari media ini adalah dapat digunakan oleh siswa sesuai keinginan, dan tingkat interaktifitas tinggi sehingga memudahkan siswa dalam memahami materi pembelajaran. Penelitian yang dilakukan oleh Purwanita, Riyanto, \& Suyanto (2019) menyatakan bahwa multimedia dapat meningkatkan berpikir kreatif pada siswa dan memudahkan siswa dalam menyerap informasi. Penelitian yang dilakukan oleh Kariadnyani, Suartama, \& Sumantri (2016) menyatakan bahwa multimedia membuat siswa senang dalam belajar sehingga berpengaruh pada hasil belajar meningkat. Penelitian yang dilakukan oleh Surjono (2016) juga menyatakan bahwa multimedia memudahkan siswa dalam belajar sehingga siswa termotivasi dalam belajar. Dapat disimpulkan bahwa media ini dapat membantu siswa dalam belajar terutama ketika siswa belajar secara mandiri.

Media yang akan dikembangkan adalah Multimedia sistem tata surya, merupakan salah satu media pembelajaran yang berbasis multimedia interaktif. Multimedia sistem tata surya ini dikembangkan menggunakan program Adobe Flash CS6. Adobe Flash CS6 merupakan aplikasi yang menyediakan berbagai macam fitur yang membantu para animator untuk membuat animasi menjadi semakin mudah dan menarik (Muyaroah \& Fajartia, 2017). Pengoperasian aplikasi ini dijalankans pada smartphone dan lebih menarik minat peserta didik untuk mencoba pempelajari materi pembelajaran. Pemilihan media aplikasi pembelajaran ini karena dalam proses pembelajaran daring diperlukan suatu media yang dapat di digunakan pembelajaran tersebut dan dapat diakses dengan mudah/praktis menggunakan smartphone pengguna. Penelitian ini bertujuan untuk mendeskripsikan proses rancang bangun dari produk Multimedia sistem tata surya dan mengetahui hasil validasi produk Multimedia sistem tata surya menurut hasil review para ahli dan uji coba perorangan. Diharapkan multimedia yang dikembangkan dapat membantu siswa dalam belajar sehingga berdampak pada hasil belajar siswa yang meningkat.

\section{Metode}

Penelitian pengembangan ini menggunakan model ADDIE yang terdiri dari lima tahap yaitu analisis (analyze), perancangan (design), pengembangan (development), implementasi (implementation), dan evaluasi (evaluation). Model pengembangan ADDIE disusun secara 
terprogram dengan urutan-urutan kegiatan yang sistematis.

Pengumpulan data dalam penelitian pengembangan ini menggunakan metode kuesioner. Metode kuesioner ini digunakan pada tahap uji coba produk yang terdiri dari ahli isi muatan pelajaran, ahli desain instruksional, ahli media pembelajaran, dan uji coba perorangan. Instrumen yang digunakan untuk mengumpulkan data penelitian pengembangan ini adalah kuesioner.

Penelitian pengembangan ini menggunakan metode analisis deskriptif kuantitatif. Metode analisis ini digunakan untuk mengolah data hasil uji coba ahli isi muatan pelajaran, ahli desain instruksional, ahli media pembelajaran, dan uji coba perorangan. Data yang dimaksud yaitu skor-skor, saran, masukan, dan komentar yang terdapat pada kuesioner

\section{Hasil dan Pembahasan}

Penelitian pengembangan ini menghasilkan produk berupa Multimedia sistem tata surya pada muatan IPA untuk kelas VI di SD N 3 Melinggih. Dalam pengembangannya, produk Multimedia sistem tata surya ini menggunakan model pengembangan ADDIE yang meliputi lima tahapan yaitu analisis (analyze), perancangan (design), pengembangan (development), implementasi (implementation), dan evaluasi (evaluation). Peneliti memilih model pengembangan ADDIE dikarenakan model pengembangan ini disusun secara sistematis dan relevan dengan produk yang ingin dikembangkan. Hal itu membantu peneliti dalam mengembangkan produk, karena peneliti memiliki pedoman dalam pengembangan produk.

Tahap analisis (analyze) merupakan tahap pertama dari model pengembangan ADDIE. Tujuan dari tahap analisis yaitu untuk mendapatkan informasi tentang kelengkapan sarana dan prasarana yang diperlukan untuk dijadikan pedoman dalam memecahkan masalah yang ditemukan dilapangan. Analisis dilakukan dengan metode observasi dan wawancara yang meliputi, analisis masalah pembelajaran, analisis lingkungan, serta fasilitas yang telah dimiliki di sekolah. Observasi dilaksanakan di SD N 3 Melinggih dan wawancara dilakukan dengan guru wali kelas VI. Pada masa pandemi COVID-19 ini, guru harus bisa memberikan suatu solusi maupun inovasi atas permasalahan yang ada di lapangan. Di dalam sistem pembelajaran daring seperti saat ini harus difasilitasi dengan sarana-prasaran pembelajaran yang mendukung terlaksananya pembelajaran daring, salah satunya adalah media pembelajaran. Permasalahan yang ditemukan oleh peneliti di SD N 3 Melinggih yaitu kurangnya media pembelajaran yang bisa diterapkan dalam proses pembelajaran daring. Biasanya dalam pelaksanaan pembelajaran daring, hanya berorientasi pada grup WhatsApp dengan menggunakan metode penugasan. Proses pembelajaran akan lebih interaktif dan menarik jika diimbangi dengan penggunaan media atau bahan ajar yang efektif. Untuk itu diperlukan sebuah media pembelajaran digital seperti Multimedia sistem tata surya yang bisa menjadi solusi atas permasalahan pada proses pembelajaran daring khususnya pada media pembelajaran. Selain menganalisis permasalahan pada proses pembelajaran, peneliti juga melakukan analisis fasilitas untuk mengetahui fasilitas pendukung dari pengembangan Multimedia sistem tata surya Dari hasil observasi yang dilakukan pada siswa kelas VI sebanyak 18 siswa, Sebagian besar siswa sudah memiliki smartphone dengan sistem operasi android. Disamping itu fasilitas yang ada di SD N 3 Melinggih cukup lengkap yaitu terdapat akses internet WiFi. Hal tersebut menjadi aspek pendukung pengembangan Multimedia sistem tata surya.

Setelah melakukan analisis dan menemukan permasalahan, peneliti selanjutnya menentukan produk yang akan dikembangkan yaitu Multimedia sistem tata surya. Selanjutnya peneliti membuat rancangan produk yang dilakukan pada tahap desain (design). Sebelum melakukan pengembangan Multimedia sistem tata surya ini, ada rancangan dan prosedur atau langkah-langkah yang ditempuh untuk membuat suatu produk. Rancangan dan langkah-langkah dari pembuatan Multimedia sistem tata surya ini divisualisasikan dalam bentuk flowchart dan storyboard yang komunikatif. Pembuatan flowchart dan storyboard ini bertujuan untuk mempermudah memahami alur kerja dan 
prosedur pembuatan dari Multimedia sistem tata surya yang akan dikembangkan. Kemudian isi dari Multimedia sistem tata surya ini tentunya juga memiliki rancangan yang perlu dipersiapkan. Pada bagian isi, peneliti mempersiapkan aspek audio yang berupa musik pendukung dan aspek visual berupa gambar, video, dan teks. Selain itu peneliti juga menyusun perangkat pembelajaran yaitu rencana pelaksanaan pembelajaran (RPP) yang digunakan sebagai pedoman untuk melaksanakan proses pembelajaran serta mempersiapkan kuesioner yang digunakan untuk mengetahui validitas produk yang dikembangkan. Kuesioner nantinya akan dibagikan kepada ahli isi muatan pelajaran, ahli desain instruksional, ahli media pembelajaran dan subjek uji coba produk yaitu uji coba perorangan.

Rancangan yang sudah dibuat pada tahap desain, selanjutnya akan diwujudkan ke dalam bentuk Multimedia sistem tata surya. Pengembangan Multimedia sistem tata surya ini lebih difokuskan pada pengembangan media pembelajaran. Multimedia sistem tata surya ini memuat menu tujuan pembelajaran, materi pembelajaran yang terdapat teks dan link video, soal latihan yang berisi 25 soal objektif dan profile pengembang. Untuk pembuatan Multimedia sistem tata surya dibuat di aplikasi Adobe Flash CS6. Dalam pembuatan Multimedia sistem tata surya ini dibuat semenarik mungkin agar siswa tertarik dan termotivasi dalam pembelajaran.

Selanjutnya yaitu tahap implementasi (implementation). Tahap implementasi ini adalah kelanjutan dari tahap pengembangan, dimana pada tahap ini produk diujicobakan untuk mengetahui respon dari pengguna produk. Sebelum produk diimplementasikan, produk divalidasi terlebih dahulu untuk mengetahui kelayakannya. Produk divalidasi oleh para ahli diantaranya: ahli isi muatan pelajaran IPA, ahli desain instruksional, ahli media pembelajaran. Dengan mempertimbangkan keterbatasan situasi dan kondisi di masa pandemi COVID-19, maka pengimplementasian produk hanya dilakukan pada uji perorangan saja. Pengimplementasian produk dengan siswa pada uji perorangan dilakukan melalui aplikasi Zoom dan kuesioner dibagikan melalui Google Forms.

Setelah produk diujicobakan kepada siswa, selanjutnya produk akan direvisi lagi pada tahap evaluasi (evaluation). Tahap evaluasi merupakan kegiatan peninjauan ulang dari produk yang sudah dikembangkan. Evaluasi yang dilakukan dibagi menjadi dua yaitu evaluasi secara formatif dan sumatif. Evaluasi formatif dilakukan untuk memperbaiki atau menyempurnakan produk, sedangkan evaluasi sumatif berfungsi untuk mengetahui tingkat keefektifan dan kebermanfaatan produk yang dilihat pada akhir program. Dengan adanya evaluasi peneliti bisa mengetahui kelebihan dan kelemahan produk yang dikembangkan, sehingga peneliti bisa melakukan perbaikan agar produk yang dikembangkan lebih baik daripada sebelumnya. Uji validitas Multimedia sistem tata surya dilakukan untuk menguji tingkat kelayakan produk. Instrumen yang digunakan untuk mengetahui validitas produk yang dikembangkan berupa kuesioner. Validitas pengembangan Multimedia sistem tata surya diuji oleh ahli isi muatan pelajaran, ahli desain instruksional, ahli media pembelajaran dan subjek pada uji coba perorangan yang hasil rangkumannya tersaji pada Tabel 1 sebagai berikut.

Tabel 1. Presentase Hasil Validitas Pengembangan Multimedia Sistem Tata Surya

\begin{tabular}{cccc}
\hline No & Subjek Uji Coba & Hasil Validitas (\%) & Keterangan \\
\hline 1 & Uji Ahli Isi Muatan Pelajaran & 87,50 & Sangat Baik \\
2 & Uji Ahli Desain instruksional & 93,75 & Sangat Baik \\
3 & Uji Ahli Media Pembelajaran & 91,66 & Sangat Baik \\
4 & Uji Coba Perorangan & 92,30 & Sangat Baik \\
\hline
\end{tabular}

Dari hasil uji coba yang telah dilakukan dengan para ahli menunjukkan bahwa, pengembangan Multimedia sistem tata surya menurut ahli isi materi memperoleh persentase sebesar $87,50 \%$ dengan kualifikasi sangat baik, hasil pengujian oleh ahli desain pembelajaran memperoleh persentase sebesar $93,75 \%$ dengan kualifikasi sangat baik, dan 
hasil pengujian oleh ahli media pembelajaran memperoleh presentase sebesar $91,66 \%$ dengan kualifikasi sangat baik. Kemudian untuk hasil uji coba perorangan yang dilakukan pada 3 (tiga) orang siswa memperoleh persentase sebesar $92,30 \%$ dengan kualifikasi sangat baik.

Dari hasil perhitungan dengan menggunakan tabel konversi skala 4, persentase yang diperoleh dari ahli isi muatan pelajaran yaitu $87,50 \%$ dengan kualifikasi sangat baik. Dari ahli isi muatan pelajaran tidak ada masukan, saran dan komentar. Jadi hal tersebut dapat dijadikan pertimbangan untuk tidak melakukan revisi. Dari hasil perhitungan yang diperoleh dari ahli desain instruksional yaitu 93,75\% dengan kualifikasi sangat baik. Dari ahli desain instruksional tidak ada masukan, saran dan komentar. Jadi hal tersebut dapat dijadikan pertimbangan untuk tidak melakukan revisi. Dari hasil perhitungan yang diperoleh dari ahli media pembelajaran yaitu $91,66 \%$ dengan kualifikasi sangat baik. Dari ahli media pembelajaran memberikan masukan yang pertama yaitu padatombol volume. revisi yang dimaksud yaitu memodifikasi tombol navigasi untuk memperbesar dan memerkecil volume suara, yang kedua membedakan antara evaluasi dan latihan, revisi yang dimaksud yaitu merubah tombol navigasi "evaluasi menjadi latihan", dan yang ketiga yaitu melengkapi menu profile pengembang dengan nomer pribadi. Dengan segala masukan, saran, dan komentar yang diberikan oleh ahli media pembelajaran dapat dijadikan pertimbangan untuk melakukan revisi. Dari hasil perhitungan yang diperoleh dari hasil uji perorangan yaitu 92,30\% dengan kualifikasi sangat baik. Dari hasil uji perorangan tidak ada masukan, saran dan komentar. Jadi hal tersebut dapat dijadikan pertimbangan untuk tidak melakukan revisi.

Setelah melakukan tahap uji coba, tentunya terdapat saran, masukan maupun yang diberikan. Saran, masukan, dan komentar yang diberikan digunakan dalam rangka menyempurnakan Multimedia sistem tata surya. Adapun revisi produk Multimedia sistem tata surya disajikan pada tabel 2.

Tabel 2. Revisi Produk Ahli Media Pembelajaran

\begin{tabular}{|c|c|c|}
\hline No & Komentar dan Saran & Revisi \\
\hline 1 & Tombol volume & $\begin{array}{l}\text { Lengkapi navigasi untuk memperbesar } \\
\text { dan mengecilkan volume }\end{array}$ \\
\hline 2 & Bedakan antara latihan dan evaluasi & $\begin{array}{l}\text { Melakukan perubahan tombol } \\
\text { navigasi dari "evaluasi menjadi latihan }\end{array}$ \\
\hline 3 & Isi nomer kontak pengembang & $\begin{array}{l}\text { Melengkapi keterangan pribadi } \\
\text { pengembang }\end{array}$ \\
\hline
\end{tabular}

Adapun hasil pengembangan produk Multimedia sistem tata surya terdiri dari, tampilan menu dan tampilan materi 1 dan 2 sebagai berikut.

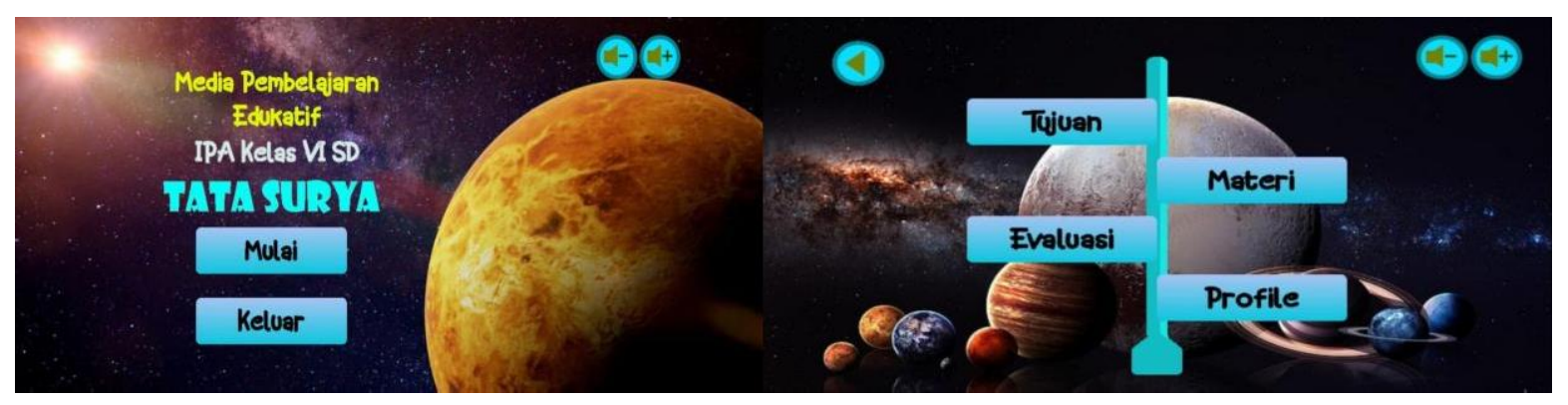

Gambar 1. Tampilan Menu pada Multimedia Sistem Tata Surya 


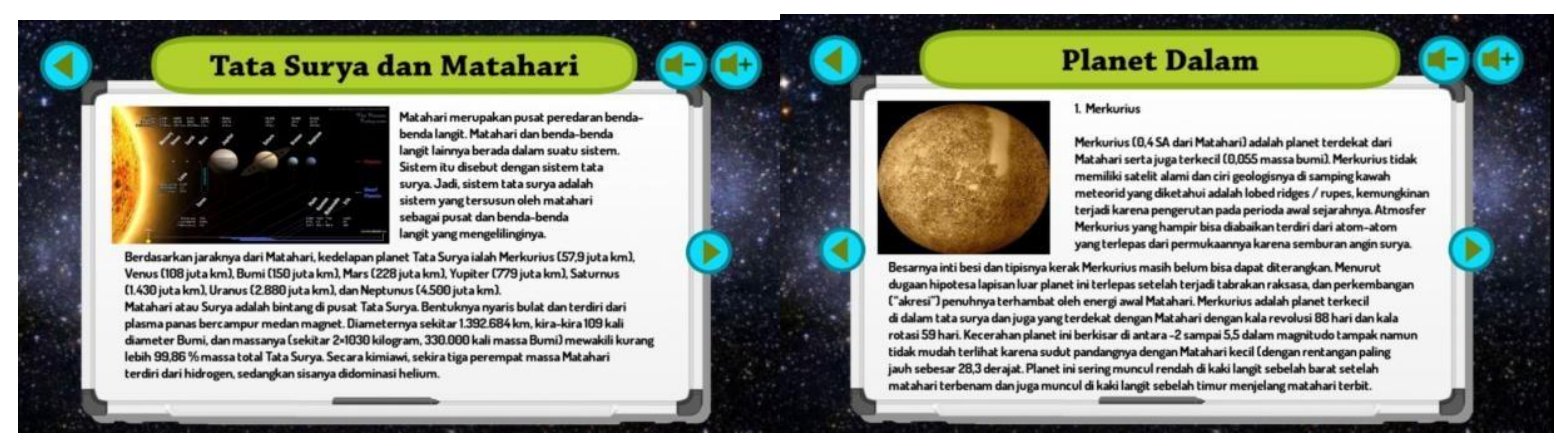

Gambar 2. Tampilan Materi Multimedia Sistem Tata Surya

Berdasarkan hasil hasil analisis data diperoleh dari ahli isi muatan pelajaran IPA, ahli desain instruksional, ahli media pembelajaran dan hasil uji coba perorangan memperoleh kualifikasi sangat baik. Maka dapat disimpulkan bahwa produk Multimedia sistem tata surya ini layak digunakan pada materi tata surya kelas VI. Produk Multimedia sistem tata surya ini layak digunakan disebabkan oleh beberapa faktor yaitu sebagai berikut.

Pertama, produk Multimedia sistem tata surya yang dikembangkan layak digunakan disebabkan karena siswa dimudahkan dalam memahami materi pembelajaran. Pada Multimedia sistem tata surya ini terdapat beberapa komponen seperti teks, gambar, audio, dan video yang digunakan untuk menunjang isi dari Multimedia sistem tata surya. Dengan hal tersebut guru dapat memberikan stimulus kepada peserta didik untuk merangsang alat indra yang dimiliki (Armansyah, Sulton, \& Sulthoni, 2019; Novitasari, 2016). Semakin banyak alat indra yang digunakan untuk menerima dan mengolah informasi maka semakin besar kemungkinan informasi yang diperoleh dapat dipahami dan diingat. Dengan demikian, peserta didik diharapkan mampu menerima dan menyerap informasi yang diberikan melalui Multimedia sistem tata surya. Siswa juga sangat mudah dalam mengoperasikan Multimedia sistem tata surya sehingga siswa merasa nyaman dalam belajar.

Kedua, produk Multimedia sistem tata surya yang dikembangkan layak digunakan disebabkan Multimedia sistem tata surya yang menarik. Kesesuaian isi materi, kelengkapan materi dan keruntutan materi dalam Multimedia sistem tata surya ini sesuai. Kemudian aspek kebahasaan dalam Multimedia sistem tata surya ini sesuai. Selanjutnya dari aspek ketepatan pemilihan video, kualitas soal, dan proporsi soal dalam Multimedia sistem tata surya tepat dan sesuai. Desain yang menarik, kesesuaian dan kengkapan materi dalam multimedia ini membuat siswa merasa tertarik dalam belajar dengan berbantuan media ini (Bardi \& Jailani, 2015; Suryanda, Ernawati, \& Maulana, 2016). Penelitian yang dilakukan oleh Sofyan, Rustono, \& Hamdu (2016) menyatakan multimedia dapat siswa tertarik dalam belajar karena menyajikan materi dengan visual maupun audio.

Ketiga, produk Multimedia sistem tata surya yang dikembangkan layak digunakan disebabkan karena Multimedia sistem tata surya dapat meningkatkan hasil belajar siswa. Kejelasan tujuan pembelajaran, kesesuaian strategi penyampaian dengan karakteristik siswa, ketepatan strategi penyampaian, kualitas memotivasi, kejelasan petunjuk pengerjaan soal, dan kualitas soal membantu siswa dalam belajar sehingga berdampak pada hasil belajar siswa. Di era modern ini guru dituntut untuk dapat menguasai berbagai keterampilan mengajar, salah satunya yaitu mampu memanfaatkan teknologi informasi dan komunikasi sebagai media dalam pembelajaran untuk meningkatkan kualitas proses pembelajaran (Darmalaksana, Hambali, Masrur, \& Muhlas, 2020; Utami \& Hasanah, 2019). Dari aspek visual seperti tampilan, teks, gambar, audio, dan video yang terdapat pada multimedia sistem tata surya ini mempermudah penyampaian informasi membantu peserta didik dalam memahami informasi yang diberikan.

Penelitian yang dilakukan oleh Manurung \& Panggabean (2020) menyatakan bahwa multimedia dapat meningkatkan kemampuan berpikir siswa dalam memecahkan masalah sehingga berdampak pada hasil belajar. Penelitian yang dilakukan oleh Kariadnyani, 
Suartama, \& Sumantri (2016) menyatakan multimedia pembelajaran dapat meningkatkan minat siswa untuk belajar sehingga berdampak pada hasil belajar siswa yang meningkat. penelitian yang dilakukan oleh Sina, Farlina, Sukandar, \& Kariadinata, (2019) juga menyatakan bahwa multimedia dapat membantu siswa dalam memahami materi dengan cepat dan dapat meningkatkan kemampuan komunikasi pada siswa. Dapat disimpulkan bahwa multimedia pembelajaran dapat memudahkan siswa dalam belajar sehingga berdampak pada hasil belajar siswa. Implikasi penelitian ini yaitu memberikan fasilitas media pembelajaran berupa multimedia yang membantu siswa dalam belajar karena dapat menfasilitasi kebutuhan belajar siswa. Multimedia pembelajaran mampu meningkatkan kompetensi siswa dan hasil belajar siswa.

\section{Simpulan}

Hasil hasil analisis data diperoleh dari ahli isi muatan pelajaran IPA, ahli desain instruksional, ahli media pembelajaran dan hasil uji coba perorangan memperoleh kualifikasi sangat baik. Disimpulkan bahwa produk Multimedia sistem tata surya ini layak digunakan pada materi tata surya kelas VI. Multimedia pembelajaran dapat membantu siswa dalam memahami materi pembelajaran sehingga berdampak pada hasil belajar siswa.

\section{Daftar Pustaka}

Antari, N. M. W., Sujana, I. W., \& Wiarta, I. W. (2013). Pengaruh Model Reciprocal Teaching (Pembelajaran Terbalik) Berbantuan Multimedia Terhadap Hasil Belajar Ips Siswa Kelas V Sd Gugus I Denpasar Selatan. Mimbar PGSD Undiksha, 1(1). https://doi.org/http://dx.doi.org/10.23887/jjpgsd.v1i1.967

Armansyah, F., Sulton, S., \& Sulthoni, S. (2019). Multimedia Interaktif Sebagai Media Visualisasi Dasar-Dasar Animasi. Jurnal Kajian Teknologi Pendidikan, 2(3), 224-229. https://doi.org/10.17977/um038v2i32019p224

Asnur, \& Ambiyar. (2018). Penerapan Pembelajaran Menggunakan Media Video Pada Mata Kuliah Tata Boga II. Jurnal Mimbar IImu, 23(3). https://doi.org/http://dx.doi.org/10.23887/mi.v23i3.16435

Bardi, \& Jailani. (2015). Pengembangan Multimedia Berbasis Komputer Untuk Pembelajaran Matematika Bagi Siswa SMA Pendidikan. Jurnal Inovasi Teknologi, 2(1), 49-63. https://doi.org/https://doi.org/10.21831/tp.v2i1.5203

Darmalaksana, W., Hambali, R. Y. A., Masrur, A., \& Muhlas. (2020). Analisis Pembelajaran Online Masa WFH Pandemic Covid-19 sebagai Tantangan Pemimpin Digital Abad 21. Karya Tulis IImiah (KTI) Masa Work From Home (WFH) Covid-19 UIN Sunan Gunung Djati Bandung Tahun 2020, 1(1), 1-12.

Handayani, Hadi, Isbaniah, Burhan, \& Agustin. (2020). Corona Virus Disease 2019. Jurnal Respirologi Indonesia, 40(2). https://doi.org/https://doi.org/10.36497/jri.v40i2.101.

Irawan, H. (2018). Keefektifan E-Learning Sebagai Media Pembelajaran (Studi Evaluasi Model Pembelajaran E-Learning Smk Telkom Sandhy Putra Purwokerto). Jurnal Inovasi Teknologi Pendidikan, https://doi.org/https://doi.org/10.21831/jpv.v3i1.1584

Irwanto, Taufik, Hernawan, \& Rizal. (2019). Efektivitas Multimedia Interaktif Dan Mobile Learning Dalam Meningkatkan Hasil Belajar Siswa Pada Mata Pelajaran Seni Budaya. Jurnal Pendidikan Dan Kajian Seni, 4(1). https://doi.org/http://dx.doi.org/10.30870/jpks.v4i1.6845.

Kariadnyani, Suartama, \& Sumantri. (2016). Pengaruh Model Course Review Horay Berbantuan Multimedia Terhadap Hasil Belajar IPA Siswa Kelas V SD. Mimbar PGSD Undiksha, 4(1). https://doi.org/http://dx.doi.org/10.23887/jjpgsd.v4i1.7467 
Khamparia, A., \& Pandey, B. (2017). Impact of interactive multimedia in E-learning technologies: Role of multimedia in E-learning. Enhancing Academic Research With Knowledge Management Principles, (April), 199-227. https://doi.org/10.4018/978-15225-2489-2.ch007

Manurung, \& Panggabean. (2020). Improving Students' Thinking Ability In Physics Using Interactive Multimedia Based Problem Solving. Cakrawala Pendidikan, 39(2), 460470. https://doi.org/https://doi.org/10.21831/cp.v39i2.28205

Muyaroah, \& Fajartia. (2017). Pengembangan Media Pembelajaran Berbasis Android dengan menggunakan Aplikasi Adobe Flash CS 6 pada Mata Pelajaran Biologi. Innovative Journal of Curriculum and Educational Technology., 6(2). https://doi.org/https://doi.org/10.15294/ijcet.v6i2.19336.

Novita, Sukmanasa, \& Pratama. (2019). Penggunaan Media Pembelajaran Video Terhadap Hasil Belajar Siswa SD. Indonesian Journal of Primary Education, 3(2), 64-72. Retrieved from https://ejournal.upi.edu/index.php/IJPE/article/view/22103

Novitasari, D. (2016). Pengaruh Penggunaan Multimedia Interaktif Terhadap Kemampuan Pemahaman Konsep Matematis Siswa. Jurnal Pendidikan Matematika \& Matematika, 2(2), 8-18.

Purwanita, Y., Riyanto, Y., \& Suyanto, T. (2019). The Influence of Multimedia Assisted Inquiry Learning Methods on My Heroes Theme of Critical Thinking Skills and Learning Outcomes of Class IV Students ofElementary School. International Journal of Scientific and Research Publications (IJSRP), 9(7), p9169. https://doi.org/10.29322/ijsrp.9.07.2019.p9169

Puspitorini, Subali, \& Jumadi. (2014). Penggunaan Media Komik Dalam Pembelajaran IPA Untuk Meningkatkan Motivasi Dan Hasil Belajar Kognitif Dan Afektif. Cakrawala Pendidikan, 33(3), 413-420. $\quad$ Retrieved from https://journal.uny.ac.id/index.php/cp/article/view/2385/pdf

Qumillaila, Susanti, \& Zulfiani. (2017). Pengembangan Augmented Reality Versi Android Sebagai Media Pembelajaran Sistem Ekskresi Manusia. Cakrawala Pendidikan, 34(1), 57-69. Retrieved from https://journal.uny.ac.id/index.php/cp/article/view/9786/pdf. \%0A

Rosidah, A. (2016). Penerapan Media Pembelajaran Visual Untuk Meningkatkan Pemahaman Konsep Siswa Pada Mata Pelajaran IPS. Jurnal Cakrawala Pendas, 2(2). https://doi.org/10.31949/jcp.v2i2.499

Sina, I., Farlina, E., Sukandar, S., \& Kariadinata, R. (2019). Pengaruh Multimedia Interaktif dalam Pembelajaran Matematika Terhadap Kemampuan Komunikasi Matematis Siswa. Suska Journal of Mathematics Education, 5(1), 57. https://doi.org/10.24014/sjme.v5i1.5081

Sofyan, Rustono, \& Hamdu. (2016). Pengembangan Media Pembelajaran Tematik Berbasis Multimedia Interaktif Pada Subtema Ayo Cintai Lingkungan. PEDADIDAKTIKA: Jurnal IImiah Pendidikan Guru Sekolah Dasar, 3(2). Retrieved from https://ejournal.upi.edu/index.php/pedadidaktika/article/view/5157

Surjono, J. (2016). Pengembangan Multimedia Pembelajaran Bahasa Inggris Untuk Pembelajaran Teks Recount Di Mtsn II Yogyakarta. Jurnal Inovasi Teknologi Pendidikan, 3(1), 25-39. https://doi.org/https://doi.org/10.21831/tp.v3i1.8287

Suryanda, Ernawati, \& Maulana. (2016). Pengembangan Modul Multimedia Mobile Learning Dengan Android Studio 4.1 Materi Keanekaragaman Hayati Bagi Siswa Sma Kelas X. Jurnal Pendidikan Biologi, 9(1), 55-64. https://doi.org/https://doi.org/10.21009/biosferjpb.9-1.9 
Susilo, Rumende, Pitoyo, Santoso, Yulianti, Herikurniawan, \& Sinto. (2020). Coronavirus Disease 2019: Tinjauan Literatur Terkini Coronavirus Disease 2019: Review of Current Literatures. Jurnal Penyakit Dalam Indonesia, 7(1). https://doi.org/http://dx.doi.org/10.7454/jpdi.v7i1.415.

Tegeh, Simamora, \& Dwipayana. (2019). Pengembangan Media Video Pembelajaran Dengan Model Pengembangan 4D Pada Mata Pelajaran Agama Hindu. Mimbar IImu Undiksha, 24(2), 158-166. Retrieved from https://ejournal.undiksha.ac.id/index.php/Ml/article/view/21262/13262

Utami, \& Hasanah. (2019). Kompetensi Profesional Guru Dalam Penerapan Pembelajaran Tematik Di SD Negeri Maguwoharjo 1 Yogyakarta. Pionir Jurnal Pendidikan, 8(2). https://doi.org/http://dx.doi.org/10.22373/pjp.v8i2.6232.

Warsihna, J. (2016). Meningkatkan Literasi Membaca dan Menulis dengan Teknologi Informasi dan Komunikasi. Kwangsan, 4(2), 67 - 80. https://doi.org/Meningkatkan Literasi Membaca dan Menulis dengan Teknologi Informasi dan Komunikasi.

Widjiningsih, Sugiyono, \& Gafur. (2014). Efektivitas Dan Efisiensi Pembelajaran Teknik Draping Berbantuan Video Di Perguruan Tinggi. Cakrawala Pendidikan, 1(33), 62-70. Retrieved from https://journal.uny.ac.id/index.php/cp/article/view/1862/pdf33

Wulandari, Sudatha, \& Simamora. (2020). Pengembangan Pembelajaran Blended Pada Mata Kuliah Ahara Yoga Semester II di IHDN Denpasar. Jurnal Edutech Undiksha, 8(1), 1-15. https://doi.org/http://dx.doi.org/10.23887/jeu.v8i1.26459

Yusnia, Y. (2019). Penggunaan Media Video Scribe Dalam Pembelajaran Literasi Sains Untuk Mahasiswa PGPAUD. Cakrawala Dini: Jurnal Pendidikan Anak Usia Dini, 10(1), 71-75. https://doi.org/https://doi.org/10.17509/cd.v10i1.17436 